\title{
PESAN PROMOSI PROGRAM TELEVISI DALAM AKUN TWITTER @NETMEDIATAMA
}

\author{
Santi Susanti ${ }^{1}$, Wina Erwina ${ }^{2}$, Tasyalia Brilianti Putri ${ }^{3}$ \\ 1,2,3Fakultas Ilmu Komunikasi, Universitas Padjadjaran \\ Jalan Raya Bandung-Sumedang Km. 21, Jatinangor, Sumedang \\ E-mail: 'santi.susanti@unpad.ac.id
}

\begin{abstract}
ABSTRAK
Penelitian ini berjudul pesan promosi dalam akun twitter @netmediatama. Ini adalah penelitian kuantitatifyang bertujuan untuk mengetahui sejauh mana pesan promosi program televisi dalam akun twitter @netmediatama berkorelasi terhadap keputusan menonton NET. Good People, sebutan bagi followers akun twitter @netmediatama. Komponen promosi yang diukur adalah intensitas promosi, isi pesan dan daya tarik pesan. Metode kuantitatif pendekatan korelasional digunakan dalam mengumpulkan dan mengolah data penelitian. Data primer penelitian dikumpulkan melalui survey menggunakan kuesioner secara random terhadap 200 NET Good People sebagai respondennya. Hasil penelitian menunjukkan adanya hubungan dengan tingkatan sedang antara intensitas promosi program di akun @netmediatama dengan keputusan menonton NET Good People; adanya tingkatan yang rendah antara isi pesan promosi program di akun twitter @netmediatama dengan keputusan menonton NET Good People; serta adanya tingkatan sedang antara daya tarik promosi program di akun @netmediatama dengan keputusan menonton NET Good People.
\end{abstract}

Kata kunci: media sosial, promosi, program televisi, keputusan menonton.

\begin{abstract}
This research title is promotional messages on twitter accounts @netmediatama. This research conducted to find out a correlation between the promote of television programs on Twitter accounts @netmediatama to the NET Good People watching decisions. The promotional component measured in this research is promotion intensity, message content, and message appeal. A quantitative method with correlational approaches employed in collecting and processing research data. Primary data collected with survey using a random questionnaire to 200 NET Good People as respondents. The results show a moderate level of correlation between the intensity of program promotion on the @netmediatama account to the Net Good People decision to watch. There is a low level correlation between the message contents of program promotion on @netmediatama to the NET Good People decision to watch; and the moderate level correlation between the appeal of the program's promotional messages on @netmediatama to the NET Good People decision to watch NET.
\end{abstract}

Keywords: social media, promotion, television program, watching decision.

\section{A. PENDAHULUAN}

Selama puluhan tahun televisi menjadi media yang paling digemari sebagai media hiburan dan informasi. Televisi mampu menghadirkan beragam acara dengan kemasan yang lebih menarik melalui tampilan audio visualnya. Banyak acara yang bisa disaksikan tanpa harus hadir langsung di lokasi, seperti pertandingan olahraga maupun pertunjukkan musik. Demikian pula dengan acara hiburan, yang bisa disaksikan secara gratis oleh jutaan pasang mata masyarakat, yang kemudian melahirkan individu-individu yang menjadi idola penonton. Karena itulah televisi dijadikan media promosi utama oleh dunia 
industri untuk memasarkan produk barang dan jasa mereka.

Seiring perkembangan teknologi, internet hadir membawa perubahan pada cara manusia berkomunikasi. Kehadiran media baru sebagai turunan dari teknologi internet, dengan sifat interaktifnya mampu membuat banyak orang tidak lagi pasif dalam berkomunikasi. Mereka tidak lagi hanya sebagai komunikan, juga sebagai komunikator. Melalui media sosial, pemilik akun dapat berkomunikasi secara interaktif, saling mengirim dan menerima informasi dengan pemilik akun lainnya secara cepat tanpa terhalang jarak dan waktu. Media sosial dapat dimanfaatkan untuk menyampaikan pesan pribadi hingga sebagai media promosi produk barang dan jasa dari individu maupun perusahaan.

Salah satu media sosial yang perkembangannya cukup pesat adalah Twitter, jejaring mikroblogging untuk mengirim dan menerima pesan dengan jumlah karakter terbatas, hanya 140 karakter (Tamburaka, 2013). Pada 7 November 2017, jumlah karakter yang dapat dimasukkan bertambah hingga 280 karakter. Pesan dalam twitter disebut kicauan atau tweets.

Twitter, yang didirikan pada 21 Maret 2006, banyak digunakan oleh pribadi maupun institusi sebagai media komunikasi dan pertemanan dengan orang lain (Fakhrurroja, 2009). Informasi yang disampaikan umumnya bersifat instan, yaitu yang terjadi pada saat itu. Melalui twitter, informasi dapat menyebar dengan cepat sehingga memungkinkan pemilik akun yang terhubung satu sama lain dapat mengetahui informasi lebih cepat. Ini sesuai dengan slogan Twitter, "It's what's happening".

Dalam perkembangannya, twitter digunakan sebagai media promosi dan pemasaran produk barang dan jasa yang dihasilkan oleh individu maupun perusahaan. Promosi bertujuan mengenalkan, meyakinkan dan memengaruhi konsumen untuk membeli atau memanfaatkan produk barang dan jasa yang dihasilkan (Rangkuti, 2009). Informasi yang mudah dimengerti dapat memancing masyarakat menjadi konsumen barang dan jasa yang ditawarkan.

Penggunaan twitter sebagai media promosi telah banyak dilakukan individu maupun perusahaan. Misalnya, jaringan bioskop terbesar di Indonesia, 21 Cineplex Group, memanfaatkan Twitter sebagai media penyampaian informasi yang berkaitan dengan film yang akan tayang di jaringan bioskopnya (Cinema XXI, Cinema 21, IMAX3D dan The Premiere), misalnya film yang akan rilis, jadwal tayang film terbaru, info midnight movie, quiz dan sebagainya. Informasi tersebut diharapkan dapat memengaruhi konsumen untuk membeli tiket menonton (Anastasia \& Herawati, tt).

Sekelompok warga Kota Semarang memanfaatkan Twitter sebagai media promosi pariwisata di ibukota Jawa Tengah tersebut, melalui akun @wisatasemarang. Akun dengan jumlah follower di atas 25 ribu tersebut berisikan konten yang mengenalkan pariwisata Semarang. Penelitian mengenai akun twitter @ wisatasemarang tersebut dilakukan oleh Anjar Pawestri Iva yang dipublikasikan pada 2014 dengan judul "Pengaruh Terpaan Media Sosial Twitter@wisatasemarang dan Kelompok Referensi Follower terhadap Minat Follower @wisatasemarang untuk Berwisata di Kota Semarang".

Melalui metode survei terhadap 100 responden, penelitian ini menghasilkan temuan akun@wisatasemarang berdampak positif terhadap perkembangan wisata Kota Semarang dan memotivasi follower untuk menjadikan@wisatasemarang sebagai media alternatif memperoleh informasi wisata di Kota Semarang.

Pemanfaatan akun Twitter sebagai media promosi pun dilakukan oleh stasiun televisi NET (News and Entertainment Television), media yang dimiliki PT. NET Mediatama Televisi, melalui akun @netmediatama. Akun yang aktif sejak November 2012 tersebut hingga April 2019 diikuti oleh 2,12 juta followers. NET memanfaatkan akun ini untuk berkomunikasi dengan khalayaknya. Sebaliknya, bagi followers, akun@netmediatama menjadi tempat untuk 
memeroleh informasi mengenai program NET setiap harinya, untuk berbagi kabar di timeline mengenai episode program yang akan tayang, informasi artis yang yang akan tampil menjadi bintang tamu dalam program NET dan sebagainya.

Sejak awal kemunculannya pada Mei 2013, NET menerapkan konsep multiplatform, yang memungkinkan pemirsanya mengakses tayangan NET dimanapun dan kapan pun melalui berbagai saluran yang disediakan, termasuk twitter sebagai saluran untuk menyampaikan pesan promosi program yang ditayangkan stasiun televisi yang mengusung slogan "Televisi Masa Kini". Akun @netmediatama menamakan followers atau pengikutnya dengan "NET Good People".

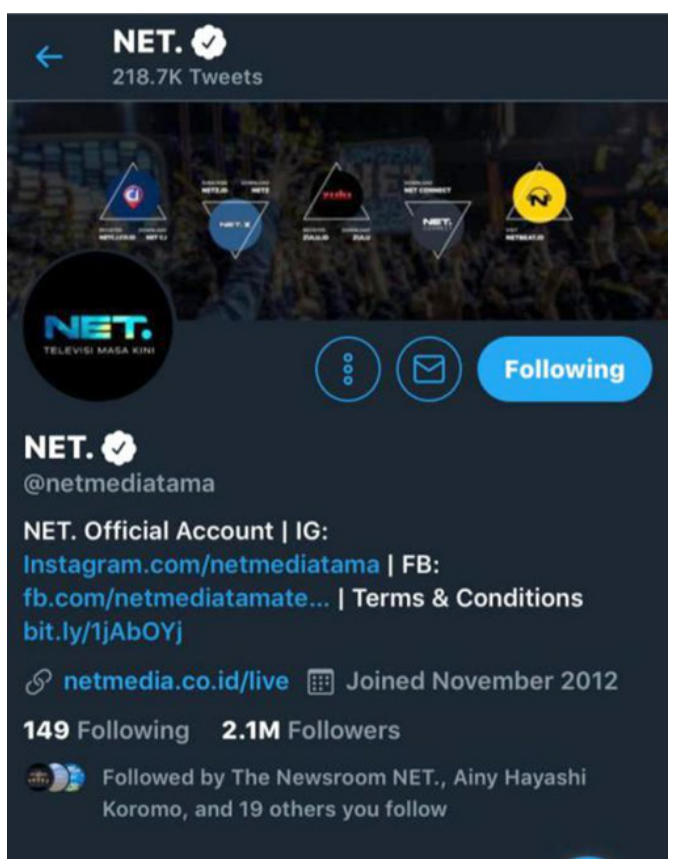

Gambar 1. Akun Twitter @netmediatama

(sumber: https://twitter.com/netmediatama)

Terpaan pesan promosi pada akun @ netmediatama diharapkan menimbulkan keinginan dan pengambilan keputusan followers akun untuk menonton programprogram NET. Berdasarkan pemaparan tersebut, rumusan masalah penelitian ini yaitu "Sejauh mana hubungan promosi program televisi di akun twitter @netmediatama terhadap keputusan menonton anggota NET. Good People?"
Tujuan penelitian ini adalah mengetahui hubungan promosi akun Twitter @ netmediatama terhadap keputusan menonton anggota NET Good People. Komponen promosi yang diterapkan dalam penelitian ini mengacu kepada perilaku penggunaan media oleh khalayak yang meliputi intensitas, isi pesan dan daya tarik pesan (Liliweri, 1992).

Intensitas diartikan sebagai waktu yang digunakan dalam mengikuti suatu media. Indikatornya adalah frekuensi dan durasi (Effendy, 1989). Frekuensi berkaitan dengan seberapa sering menggunakan media dalam periode waktu tertentu. Durasi merupakan lamanya waktu yang dibutuhkan untuk menggunakan media, diukur berdasarkan lamanya khalayak bergabung dengan suatu media atau berapa lama mengikuti sutau program (Ardianto, 2007)

Isi pesan berkaitan dengan kejelasan dan kelengkapan informasi yang disampaikan. Indikatornya adalah kejelasan informasi dan kelengkapan informasi. Informasi yang jelas adalah informasi yang mudah dipahami oleh penerima pesan. Untuk itu, isi pesan yang disampaikan harus rinci, sistematis, dan pilihan katanya diketahui secara umum (Soemirat dan Elvinaro, 2002). Selain itu, tidak tidak menimbulkan makna ganda (ambigu) dan dapat mengungkapkan gagasan secara cermat (Rakhmat, 2011).

Informasi yang lengkap adalah informasi yang disampaikan menyeluruh dan rinci sehingga dapat diterima dan dipahami dengan baik karena tidak menimbulkan keraguan pada penerima pesan atau penggunanya. Informasi yang lengkap berasal dari narasumber yang jelas dengan dukungan data yang lengkap sebagai pendukung kejelasan dan keberagaman informasi (Nitisemito, 1996).

Daya tarik pesan berkaitan dengan bagaimana pesan tersebut dikemas. Pengemasan pesan dengan dukungan penggunaan gambar, foto, video maupun pemilihan kata, dapat menarik perhatian followers untuk menindaklanjuti pesan. Foto dan gambar merupakan stimuli nonverbal yang dapat memperkuat argumen pesan 
(Schiffman dan Kanuk, 2007). Penggunaan foto dan gambar, dapat menarik perhatian dan memicu afeksi pada diri followers. Begitu pula dengan penggunaan kata-kata yang jelas dan pantas dapat memunculkan kesan kuat, hidup dan merebut perhatian khalayak (Rakhmat, 2011).
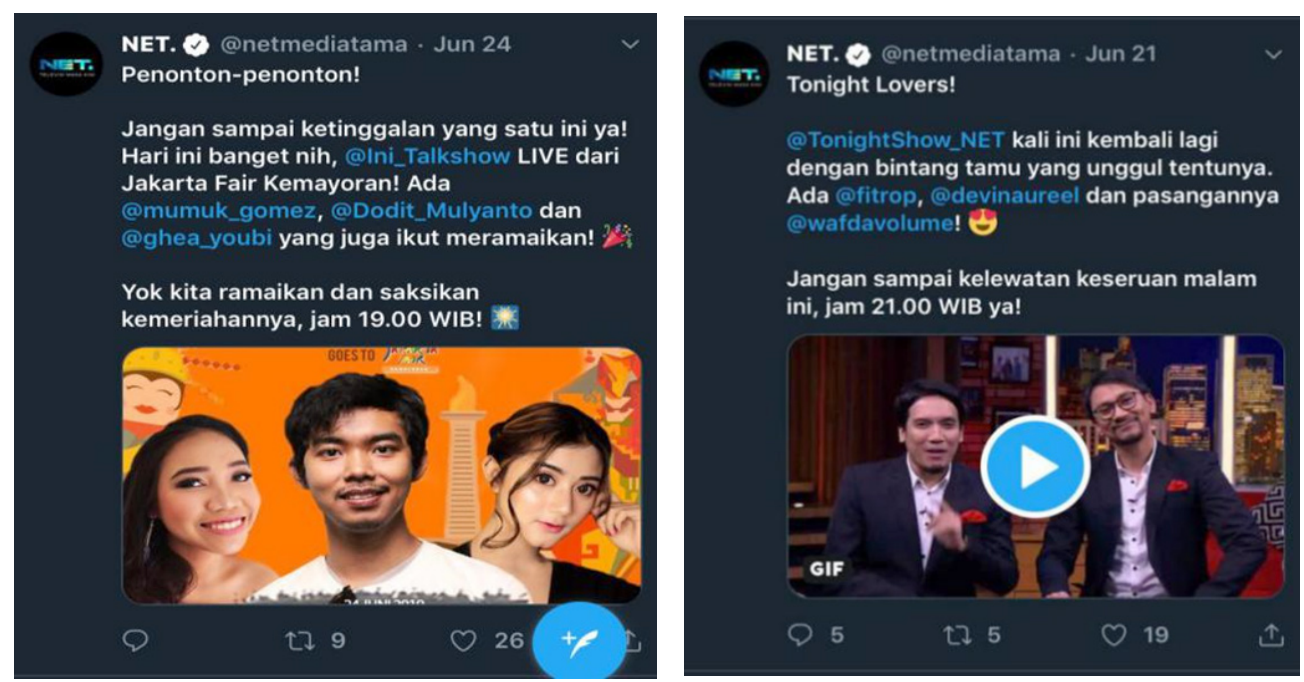

Gambar 2 \& 3 Promosi Program dalam akun twitter @netmediatama (sumber: https://twitter.com/netmediatama)

\section{B. TINJAUAN PUSTAKA}

Penelitian ini menggunakan beberapa teori sebagai acuan, yaitu Teori Proses Selektif, Teori Uses \& Gratification, serta Teori Pencarian Informasi. Menurut Teori Proses Selektif yang dikemukakan oleh Joseph Klapper (1960), orang-orang cenderung melakukan selective exposure (terpaan selektif) dengan menolak pesan yang tidak sesuai dengan kepercayaan mereka. Media memiliki pengaruh yang lemah, terutama bagi pemilih dalam pemilihan umum, pasar saham dan para pengiklan (Ardianto, 2007).

Model komunikasi massa yang dipakai dalam penelitian ini adalah Uses and Gratifications, yang merupakan pengembangan dari Teori Jarum Hipodermik. Model Uses \& Gratification tidak tertarik pada perilaku media terhadap diri seseorang, melainkan pada perilaku orang terhadap media untuk memenuhi kebutuhannya (Ardianto, 2009). Khalayak merupakan sosok yang aktif dalam memilih media yang akan digunakannya untuk memenuhi kebutuhannya akan informasi.

Teori Uses and Gratifications relevan dengan penelitian ini, karena followers akan melakukan seleksi terhadap program yang akan ditonton setelah mendapatkan terpaan promosi dari program-program NET di akun@netmediatama. Disini followers dianggap aktif dalam menggunakan pencarian informasi terkait program NET. yang nantinya pencarian informasi tersebut akan berdampak kepada diri masingmasing followers apakah sudah memenuhi kebutuhannya atau tidak.

Teori lainnya adalah Teori Pencarian Informasi (Information Seeking Theory) yang dikemukakan oleh Donohew dan Tipton (1973). Teori ini selaras dengan uses \& gratifications yang menekankan pada keaktifan individu dalam mencari informasi untuk memenuhi kebutuhannya. Menurut Teori Pencarian Informasi, orang cenderung menghindari informasi yang tidak sesuai dengan image of reality-nya karena dianggap membahayakan, namun individu akan memilih sumber-sumber informasi yang dapat menambah ilmu pengetahuan melalui informasi-informasi baru dalam proses pengembangan diri (Yusup, 2010).

Menurut Sutopo (2012), informasi yang baik adalah informasi yang relevan, akurat, tepat waktu, ringkas, jelas, dapat diukur dan konsisten. Relevan berkaitan dengan 
kemampuan informasi dalam mendukung pengambilan keputusan; Akurat berarti informasi tersebut bebas dari kesalahan dan tidak menyesatkan pengguna informasi sehingga dapat diandalkan; Tepat waktu, artinya informasi tersedia pada saat dibutuhkan sehingga dapat digunakan dalam proses pengambilan keputusan; Ringkas, berarti informasi tersebut disajikan dalam format yang sederhana sehingga tidak membingungkan para pemakai informasi; Jelas, berarti informasi yang disajikan tingkat abstraksinya mudah dipahami; Dapat diukur, berhubungan dengan konsep informasi yang nilainya dapat diestimasi; Konsisten, informasi tersebut dapat dibandingkan dengan informasi sejenis dari fungsi yang berbeda atau informasi yang sejenis dengan waktu yang berbeda.

\section{METODE PENELITIAN}

Penelitian ini merupakan metode kuantitatif dengan pendekatan studi korelasional, yakni menghubungkan suatu variabel dengan variabel lain untuk memahami suatu fenomena dengan cara menentukan tingkat atau derajat hubungan di antara variable-variabel tersebut (Indra, 2019). Dalam penelitian kuantitatif, data disajikan berupa angka-angka yang dianalisis menggunakan statistik (Sugiyono, 2012)

Penelitian ini menggunakan skala pengukuran ordinal atau likert, untuk mengukur sikap, pendapat dan persepsi seseorang atau sekelompok orang tentang fenomena sosial (Sugiyono, 2012). Fenomena sosial yang dimaksud ditetapkan oleh peneliti secara spesifik dan disebut variabel penelitian.

Studi korelasional digunakan untuk meneliti populasi atau sampel tertentu, menggunakan instrumen penelitian untuk pengumpulan data, yang dianalisis secara kuantitatif untuk menguji hipotesis yang telah ditetapkan (Sugiyono, 2018)".

Dalam penelitian ini, data dikumpulkan melalui kuesioner, wawancara serta studi dokumentasi dan literatur. Kuesioner disebar kepada responden dengan teknik insidental sampling atau sample secara kebetulan, yaitu siapa saja yang ditemui peneliti, bila dipandang cocok sebagai sumber data, maka dapat digunakan sebagai sampel penelitian (Sugiyono, 2013).

Kuesioner disebar kepada 200 responden melalui online chat. Responden penelitian ini adalah followers akun twitter @netmediatama yang tergabung dalam komunitas NET Good People. Jumlah responden diperoleh melalui penghitungan rumus Yamane dengan presisi 5\% terhadap 400 orang anggota komunitas NET Good People. Penghitungannya sebagai berikut:

$$
\begin{aligned}
& n=\frac{400}{400(0,0025)+1} \\
& n=200
\end{aligned}
$$

$$
\begin{aligned}
& n \text { : Jumlah Sampel } \\
& \text { N : Jumlah Populasi (400 orang) } \\
& d \text { : Presisi yang ditetapkan (5\%) }
\end{aligned}
$$

Penyebaran dan pengumpulan kuesioner dilakukan satu bulan pada Juli 2019. Wawancara dilakukan kepada koordinator NET. Good People Bandung dan staff new media NET. melalui chat. Studi dokumentasi dilakukan dengan melihat dan memperhatikan perkembangan timeline dari akun twitter@netmediatama serta sikap followers dalam menanggapi informasi tersebut melalui reply, retweet dan like yang dilakukan selama periode yang telah ditentukan.

Penelitian ini menguji hipotesis secara empirik. Hipotesis merupakan bentuk pernyataan yang menghubungkan dua variabel atau lebih. Hipotesis merupakan jawaban sementara yang memerlukan pengujian secara empirik. Kriteris hipotesis yang diterima menggunakan hipotesis kerja $(\mathrm{H} 1)$ dan hipotesis nol $(\mathrm{HO})$ sebagai pembandingnya, yang merupakan formulasi terbalik dari hipotesis kerja (Sugiyono, 2009: 64).

Hipotesis kerja ( $\mathrm{H} 1)$ menyatakan adanya hubungan antara variabel $X$ dengan variabel $\mathrm{Y}$, sedangkan hipotesis nol ( $\mathrm{HO})$ adalah 
pernyataan tidak adanya hubungan antara variabel $X$ dengan variabel $Y$. Hipotesis penelitian ini meliputi tiga aspek pernyataan yang terdiri dari intensitas promosi, isi pesan dan daya tarik pesan.

\section{Hipotesis Mayor}

- HO: Tidak ada hubungan antara terpaan promosi program NET. TV melalui akun @netmediatama dengan keputusan menonton

- H1: Terdapat hubungan antara terpaan promosi program NET. TV melalui akun @netmediatama dengan keputusan untuk menonton.

\section{Hipotesis Minor}

H0: Tidak ada hubungan antara intensitas promosi program NET. TV melalui akun twitter @netmediatama dengan keputusan menonton

$\mathrm{H} 1$ : Adanya hubungan antara intensitas promosi program NET. TV melalui akun twitter @netmediatama dengan keputusan menonton

H0: Tidak ada hubungan antara isi pesan promosi program NET. TV melalui akun twitter @netmediatama dengan keputusan menonton

$\mathrm{H} 1$ : Adanya hubungan antara isi pesan promosi program NET. TV melalui akun twitter@netmediatama dengan keputusan menonton

HO: Tidak ada hubungan antara daya tarik pesan promosi program NET. TV melalui akun twitter @netmediatama dengan keputusan menonton

$\mathrm{H} 1$ : Adanya hubungan antara daya tarik pesan promosi program NET. TV melalui akun twitter @netmediatama dengan keputusan menonton

\section{TEMUAN DAN BAHASAN}

Berikut ini diuraikan pengelompokan responden berdasarkan jenis kelamin, usia, pendidikan terakhir, pekerjaan, dan lama waktu menjadi followers akun twitter @ netmediatama.
Tabel 1. Karakteristik Responden Berdasarkan Jenis Kelamin

\begin{tabular}{ccc}
\hline Jenis Kelamin & $\mathbf{f}$ & $\%$ \\
\hline Perempuan & 148 & 74,0 \\
Laki-Laki & 52 & 26,0 \\
\hline Total & 200 & 100
\end{tabular}

Berdasarkan Tabel 1, dari 200 orang responden, jumlah perempuan lebih banyak daripada laki-laki. Ini menunjukkan bahwa perempuan cenderung lebih aktif menggunakan media sosial dibandingkan laki-laki. Hal ini selaras dengan pernyataan Muhammad Uyun, "aktifnya para perempuan di media sosial ditengarai karena disebabkan oleh sifat dasar yang dimiliki oleh sebagian perempuan. Ada yang sangat suka diperhatikan oleh orangorang yang mereka kenal dan refleks dari sifat suka diperhatikan itu beberapa di antaranya adalah aktif di dunia media sosial". (Uyun, 2016).

Tabel 2. Karakteristik Responden Berdasarkan Usia

\begin{tabular}{|l|c|c|}
\hline \multicolumn{1}{|c|}{ Usia } & $\mathbf{f}$ & $\mathbf{\%}$ \\
\hline $17-<20$ thn & 38 & 19,0 \\
\hline $20-<23$ th & 143 & 71,5 \\
\hline $23-<26$ thn & 15 & 7,5 \\
\hline $26-30$ thn & 2 & 1,0 \\
\hline Lainnya & 2 & 1,0 \\
\hline \multicolumn{1}{|c|}{ Total } & 200 & 100 \\
\hline
\end{tabular}

Data Riset APJII (Asosiasi Penyelenggara Jasa Internet Indonesia) tahun 2018, menunjukkan bahwa generasi muda dalam rentang usia 2024 memiliki angka penetrasi lebih tinggi dibandingkan penduduk kelompok usia lainnya. Pada kategori 20-24 tahun ditemukan 22,3 juta jiwa yang setara $82 \%$ dari total penduduk di kelompok itu. Profesi mahasiswa merupakan yang paling banyak menggunakan internet dibandingkan lainnya karena keburuhan informasinya sangat tinggi (Sugiharto, 2016). Berdasarkan hasil wawancara dengan Restu Mardika (staff 
NET. sosial media), target usia untuk followers akun twitter @netmediatama adalah pada usia 18-34 tahun. Sangat berkesinambungan dengan hasil data yang menunjukkan usia 20-23 tahun masih aktif menggunakan Twitter dan menjadi followers@netmediatama.

Tabel 3. Karakteristik Responden Berdasarkan Pendidikan Terakhir

\begin{tabular}{lcc}
\hline Pendidikan Terakhir & $\mathbf{f}$ & $\%$ \\
\hline SMP & 1 & 0,5 \\
SMA & 127 & 63,5 \\
D3 & 8 & 4,0 \\
S1 & 62 & 31,0 \\
Lainnya & 2 & 1,0 \\
\hline \multicolumn{1}{c}{ Total } & 200 & 100 \\
\hline
\end{tabular}

Katz, Gurevitch, dan Haas (dalam Yusup, 1995) menyatakan dalam penelitiannya bahwa orang yang tingkat pendidikannya tinggi lebih banyak mempunyai kebutuhan dibandingkan dengan orang berpendidikan rendah. Dari tabel diatas, dapat dilihat bahwa banyak sekali variasi latar belakang followers akun twitter @netmediatama. Mayoritas responden memiliki latar belakang pendidikan terakhir pada jenjang SMA/SMK. Target dari akun twitter @ netmediatama sendiri adalah millenial yang memang sudah lulus SMA namun masih dalam pendidikan sebagai mahasiswa. Dari data fanbase NET. Good People Bandung sendiri, bahwa anggota aktif NGP Bandung mempunyai anggota dengan kisaran umur 17-30 tahun dengan dominan usia 20 tahunan. Apabila dihubungkan dengan tabel usia responden dimana mayoritas berasal pada usia 20-23 tahun, dapat ditarik kesimpulan bahwa responden banyak merupakan orang yang masih menempuh pendidikan S1/ mahasiswa dan sudah lulus dari jenjang SMA. Dikarenakan memang usia 20-23 tahun banyak sekali membutuhkan informasi lebih tinggi dan banyak untuk mencari lowongan pekerjaan, tugas pendidikan, research, dan lainnya.
Tabel 4 Karakteristik Responden Berdasarkan Pekerjaan

\begin{tabular}{|l|c|c|}
\hline \multicolumn{1}{|c|}{ Pekerjaan } & $\mathbf{f}$ & \% \\
\hline Swasta & 2 & 1,0 \\
\hline Wiraswasta & 24 & 12,0 \\
\hline PNS & 4 & 2,0 \\
\hline Mahasiswa & 148 & 74,0 \\
\hline Lainnya & 22 & 11,0 \\
\hline Total & 200 & 100 \\
\hline
\end{tabular}

Berdasarkan tabel 4, diketahui bahwa latar belakang pendidikan responden sebagian besar adalah mahasiswa, yakni 148 orang atau 74 persen dari total responden. Sekjen APJII, Henri Kasyfi, menerangkan bahwa pengguna internet dengan umur 20-24 tahun, masuk dalam posisi kedua dengan presentase $88,5 \%$ dalam survey yang dilakukan oleh APJII tahun 2018. Para pengguna internet menghabiskan waktu sekitar 3-4 jam sehari untuk berkomunikasi lewat pesan, media sosial dan mencari informasi terkait pekerjaan. (Maharrani, 2019 beritagar.id).

Tabel 5 Karakteristik Responden Berdasarkan Lama Waktu Menjadi Followers

\begin{tabular}{ccc}
\hline Lama Waktu Menjadi Followers & $\mathbf{f}$ & $\boldsymbol{\%}$ \\
\hline$<6 \mathrm{bln}$ & 67 & 33,5 \\
$>6 \mathrm{bln}$ & 35 & 17,5 \\
$>1$ thn & 59 & 29,5 \\
$>3$ thn & 39 & 19,5 \\
Total & 200 & 100 \\
\hline
\end{tabular}

Berdasarkan tabel diatas, diketahui bahwa dari 200 responden, terdapat 67 responden atau sebesar 33,50\% sudah menjadi followers @netmediatama selama kurang dari 6 bulan, 35 responden atau sebesar 17,50\% sudah menjadi followers @netmediatama selama lebih dari 6 bulan, 59 responden atau sebesar 29,50\% sudah menjadifollowers@netmediatama selama lebih dari 1 tahun, 39 responden atau sebesar 19,50\% sudah menjadi followers @ netmediatama selama lebih dari 3 tahun. 
Terpaan dapat diukur dari intensitas penggunaan dengan melihat frekuensi dan durasi ketika menggunakan media. Selain mengacu pada frekuensi penggunaan media, durasi penggunaan media juga digunakan sebagai indikator untuk mengetahi seberapa besar intensitas penggunaan media pada seseorang. Menurut Ardianto dan Komala (2004), durasi adalah seberapa lama pengguna menggunakan media tersebut. Hal tersebut dapat dihitung berapa lama khalayak bergabung dengan suatu media atau mengikuti suatu program.

Dari pernyataan diatas, followers yang berinteraksi dan mengakses akun twitter @netmediatama adalah followers yang sudah mem-follow kurang dari 6 bulan yang dapat dikategorikan followers baru. Dalam kasus seperti ini terlihat bahwa responden memang masuk dalam kategori baru menjadi followers @netmediatama. Namun hal ini menjadikan hal baru yaitu tidak butuh waktu lama bagi followers untuk memahami isi dari akun @netmediatama. Dalam waktu <6 bulan, beberapa responden sudah dapat memahami isi tweet promosi akun @ netmediatama.

\section{Hubungan antara intesitas promosi program NET. melalui akun twitter @netmediatama dengan keputusan menonton}

Hasil uji hipotesis menunjukkan adanya hubungan dalam tingkatan sedang antara intensitas promosi program melalui akun @netmediatama dengan keputusan menonton. Hal ini menunjukkan bahwa seringnya penggunaan media, baik frekuensi maupun durasi penggunaannya, membuat masyarakat pengguna mendapat terpaan informasi yang disampaikan sehingga mempengaruhi keputusannya untuk membeli.

Hubungan ini dihasilkan dari seringnya followers membaca tweet promosi program pada akun @netmediatama, dengan jangka waktu cukup untuk membaca dan memahami informasi mengenai promosi program serta muncul tindakan feedback yang dilakukan followers berupa reply, retweet dan love promosi program NET.
Hal ini sejalan dengan pernyataan Djaslim (2003) mengenai promosi, bahwa komunikasi bertujuan yang terjalin antara penjual dan pembeli menjadikan yang tidak mengenal menjadi mengenal sehingga membeli dan tetap mengingat produk tersebut.

\section{Hubungan antara isi pesan promosi program NET. melalui akun twitter @netmediatama dengan keputusan menonton}

Hasil uji hipotesis menunjukkan adanya hubungan dalam tingkatan rendah antara isi pesan promosi program melalui akun@netmediatama dengan keputusan menonton.

Kelengkapan informasi berpengaruh terhadap individu dalam pengambilan keputusan. Informasi yang lengkap, mudah dimengerti dan tepat waktu, dapat menghilangkan keraguan dari pengguna media sehingga keputusan yang diambil tepat.

Indikator lainnya dari isi pesan yang disampaikan adalah kejelasan informasi. Untuk dapat dimengerti oleh khalayak, media harus dapat memberikan informasi yang jelas. Pesan yang disampaikan harus rinci, sistematis dan menggunakan kata yang sudah diketahui secara umum (Soemirat dan Elvinaro, 2002).

Sebagian besar responden berpendapat bahwa informasi promosi program NET. pada akun @netmediatama mudah dimengerti dan cukup jelas. Dengan demikian, infomasi (isi pesan) pada akun @netmediatama berpotensi untuk mempengaruhi dan menimbulkan suatu keinginan atau tindakan untuk menonton karena penyampaian pesan (informasi) mudah dimengerti oleh followers.

\section{Hubungan antara daya tarik pesan promosi program NET. melalui akun twitter @netmediatama dengan keputusan menonton}

Hasil uji hipotesis pada penelitian ini menunjukkan terdapat hubungan dalam tingkatan sedang antara daya tarik promosi program melalui akun @netmediatama dengan keputusan menonton. 
Daya tarik promosi merupakan satu dari tiga perilaku penggunaan media yang dikemukakan oleh Alo Liliweri (1992). Daya tarik promosi berkaitan dengan pemilihan kata-kata dan gambar atau foto yang menarik dan persuasif untuk menarik perhatian dan mengajak followers mengikuti ajakan dalam pesan yang disampaikan.

Sebagian besar responden berpendapat bahwa pesan promosi melalui gambar, video \& foto dalam akun @netmediatama sudah cukup menarik dan jelas serta videonya pun sudah beresolusi HD sehingga menarik perhatian dan menimbulkan rasa keingintahuan pada program NET.

\section{E. KESIMPULAN}

Berdasarkan hasil penelitian dan tujuan penelitian, maka dapat disimpulkan bahwa:

1. Terdapat hubungan antara intensitas tweet promosi program pada akun @netmediatama dengan keputusan menonton, pada tingkatan sedang dan hubungan kedua variabel searah. Semakin tinggi intensitas promosi maka semakin tinggi keputusan untuk menonton.

2. Terdapat hubungan antara isi pesan tweet promosi program NET dengan keputusan menonton, dalam tingkatan rendah dan memiliki hubungan searah. Semakin jelas dan lengkap isi pesan promosi maka semakin besar peluang keputusan untuk menonton. Hal ini disebabkan, informasi yang terkandung dalam tweet promosi @netmediatama sudah jelas, lengkap dan menggunakan kata-kata yang mudah dimengerti oleh followers sehingga menimbulkan keinginan untuk membaca isi pesan tweet promosi.

3. Terdapat hubungan antara daya tarik tweet promosi program dengan keputusan NET Good People menonton NET, dalam tingkatan sedang dan hubungannya searah. Semakin tinggi daya tarik pesan promosi maka semakin tinggi keputusan untuk menonton. Hal ini disebabkan penggunaan kata-kata pada tweet yang dapat mempersuasi serta menarik perhatian followers. Disamping itu, penggunaan gambar, teaser \& foto yang di-posting bersamaan dengan tweet promosi juga dapat menarik perhatian dan menimbulkan rasa keingintahuan setelah melihat poster/ teaser pada tweet promosi program NET.

\section{REFERENSI}

Anastasia, G. \& Herawati, F. A.. (tt) Pengaruh Intensitas Terpaan Informasi melalui Twitter @cinema21 terhadap Tingkat Keputusan Pembelian yang dikontrol oleh Sikap dan Tingkat Motif Pembelian Tiket Bioskop pada Followers @cinema21. https://core.ac.uk/ download/pdf/35388936.pdf

Ardianto, E.(2005). Komunikasi Massa. Bandung: Simbiosa Rekatama Media.

Ardianto, E. dan Erdinaya, L.K. (2007). Komunikasi Massa: Suatu Pengantar. Bandung: Remaja Rosdakarya.

Fakhrurroja, H. (2009). Twitter Ngoceh Dapet Duit. Yogyakarta: Great Publisher

Febriani, S.N \& Dewi, W.W.A. (2018). Teori dan Praktis Riste Komunikasi Pemasaran Terpadu. Malang: UB Press

Indra, I.M \& Cahyaningrum, I. (2019). Cara Mudah Memahami Metodologi Penelitian. Yogyakarta: Budi Utama

Iva, A.P. (2014). Pengaruh Terpaan Media Sosial Twitter @wisatasemarang dan Kelompok Referensi Follower terhadap Minat Follower @wisatasemarang untuk Berwisata di 
Kota Semarang. Tesis. Semarang: Universitas Diponegoro. http://eprints.undip. ac.id/45567/

Liliweri, A. (1992). Dasar-Dasar Komunikasi Periklanan. Bandung: Citra Aditya Bakti

Nitisemito, A. (1996). Manajemen Personalia Cetakan Sembilan. Jakarta: Ghalia Indonesia

Rangkuti, F. (2009). Strategi Promosi yang Kreatif dan Analisis Kasus Integrated Marketing Communication. Jakarta: Gramedia Pustaka Utama.

Rakhmat, J. (2011). Psikologi Komunikasi: Bandung: Remaja Rosdakarya

Shimp, T.A. (2003). Periklanan Promosi Aspek Tambahan Komunikasi Pemasaran Terpadu. Jakarta: Erlangga

Soemirat, S. \& Ardianto, E. (2002). Dasar-DasarPublic Relations. Bandung: Remaja Rosdakarya

Sugiyono. (2010). Metode Penelitian Pendidikan Pendekatan Kuantitatif, Kualitatif, dan R\&D. Bandung: Alfabeta (2012). Metode Penelitian Komunikasi. Bandung: Alfabeta (2013). Metode Penelitian Kuantitatif Kualitatif dan R\&D. Bandung: Alfabeta. (2018). Metode Penelitian Manajemen. Bandung: Alfabeta.

Sutopo, A. (2012). Teknologi informasi dan Komunikasi dalam Pendidikan. Yogyakarta: Graha IImu

Tamburaka, A. (2013). Literasi Media. Jakarta: Rajagrafindo Persada

Yusup, P.M. \& Subekti, P. (2010). Teori \& Praktik Penelusuran Informasi (Information Retrieval). Jakarta: Kencana Prenada Media Group. 